\title{
Revision of type materials of antarctic diatom species (Bacillariophyta) described by West \& West (1911), with the description of two new species
}

\author{
Bart Van De ViJver ${ }^{1 *}$, Ines TavernieR ${ }^{2}$, Thomas B. KellogG ${ }^{3}$, John Gibson $^{4}$, Elie \\ VERLEYEN ${ }^{2}$, Wim VYVERMAN ${ }^{2} \&$ Koen SABBE $^{2}$
}

\author{
${ }^{1}$ National Botanic Garden of Belgium, Department of Bryophyta \& Thallophyta, Domein van Bouchout, B-1860 \\ Meise, Belgium; *Corresponding authore-mail: vandevijver@br.fgov.be, tel.: +32 226009 41, fax : +32 2260 \\ 0945 \\ ${ }^{2}$ University of Ghent, Department of Biology, Protistology \& Aquatic Ecology, Krijgslaan 281 S8, 9000 Ghent, \\ Belgium \\ ${ }^{3}$ University of Maine, Department of Geological Sciences and Institue for Quaternary studies, Orono, ME 04469, \\ USA \\ ${ }^{4}$ Institute for Marine and Antarctic Science, University of Tasmania, Hobart, Tasmania, Australia
}

\begin{abstract}
In 1911, W. \& G.S. West published a detailed account of freshwater algae collected by James Murray in the vicinity of Cape Royds on Ross Island (Antarctic Continent). Out of of 84 algal taxa reported, 30 were diatoms. Although the majority of the diatoms were considered (at that time) to be cosmopolitan, eight diatom species and two varieties were described as new. While most of these new taxa are still commonly reported from Antarctic and Subantarctic localities, the exact identity of some remains uncertain. Here we document the morphology of these species from the original type material using light and scanning electron microscopy; the taxonomic identities are discussed and, where necessary, the taxonomy is updated. For several species, lectotypes are designated. In addition, two Antarctic species are described as new: Luticola pseudomurrayi VAN DE VIJVER et TAVERNIER sp. nov. and Chamaepinnularia gibsonii VAN DE VIJVER sp. nov.
\end{abstract}

Key words: Antarctica, Bacillariophyta, diatoms, morphology, new species, type material, West \& West

\section{Introduction}

The oldest diatom records from the Antarctic Continent date back to the beginning of the $20^{\text {th }}$ century (Holmboe 1902; Van Heurck 1909; West \& West 1911; Fritsch 1912, 1917; Carlson 1913; Brown 1920) when diatoms, including new species, were described from collections made during Belgian, British, German and Danish Polar Expeditions. One of the most important contributions of this pioneer era was made by William West (Roebuck 1914) and his son George Stephen West (Grove 1919) with their publication in 1911 of a detailed account of freshwater algae collected in 1908 and 1909 by James Murray in the vicinity of the winter quarters of the British Expedition near Cape Royds on Ross Island $\left(77^{\circ} 30^{\prime} \mathrm{S}-168^{\circ} 00^{\prime} \mathrm{E}\right)$. Among the 84 algal species reported in their paper, they list and describe 30 diatom taxa. Although the majority of these diatoms were at the time considered to be cosmopolitan, West \& West also described eight new diatom species. Several of these, such as Chamaepinnularia cymatopleura (W. WEST et G.S. West) Cavacini, Muelleria peraustralis (W. West et G.S. West) Spaulding et Stoermer, and Luticola murrayi (W. West et G.S. WeST) D.G. MANN (all originally described as Navicula species), Navicula shackletoni W. et G.S. WEST and Craspedostauros laevissimus (W. WEST et G.S. West) SABbe (originally Tropidoneis laevissima) are commonly reported in publications on contemporary diatoms from the Antarctic Continent (Spaulding et al. 1997; SabBe et al. 2003; GiBson et al. 2006).

The present paper discusses the morphology and phenotypic variability of the new species described in West \& WeST (1911) using modern SEM and LM techniques. The original description and drawings are verified and discussed on the 
basis of the original West \& West slides. For each species, light micrographs of the original type slides and scanning electron micrographs (using other materials from recent collections) are provided and comparisons with other taxa are made in order to clarify the taxonomical position of the West \& West species. West \& WeSt (1911) did not designate holotype slides. Since apart from Chamaepinnularia cymatopleura (CAVACINI et al. 2006), this was never done for the other species described in WeST \& WeST (1911), we formally lectotypify all new species described in their paper, except for Navicula muticopsiforme, as we did not find the species in the slides.

Additionally, Luticola pseudomurrayi VAN De ViJver et TaVernier sp. nov. and Chamaepinnularia gibsonii VAN DE VIJVER sp. nov., both observed on the Antarctic Continent, are described as new species.

\section{Material and Methods}

Table 1 lists all original slides made by WeST \& WeST (1911), stored in the British Museum, together with the available sample information. Light micrographs from the original slides have been made for species described as new by West \& West (1911) in order to document the morphological variability of the populations. Since no raw materials of the original slides were kept, samples from recent collections from similar environments in other regions on the Antarctic Continent (viz. the Bunger Hills, East-Antarctica and Taylor Valley, McMurdo Dry Valleys) have been investigated in order to provide SEM observations of specimens fully matching the original West \& West species. Table 2 lists all samples used. Diatom samples of this material were prepared following the method of VAN DER WeRFF (1955). Small parts of the samples were cleaned by adding $37 \% \mathrm{H}_{2} \mathrm{O}_{2}$ and heating to $80{ }^{\circ} \mathrm{C}$ for about $1 \mathrm{~h}$ where after the reaction was completed by addition of $\mathrm{KMnO}_{4}$. Following digestion

Table 1. List of West \& West samples present in the Natural History Museum, London.

\begin{tabular}{|c|c|c|c|}
\hline Slide number & Sample description & Collector & $\begin{array}{l}\text { additional information on slide } \\
\text { label }\end{array}$ \\
\hline BM 34116 & Green Lake, Cape Royds & Coll. J. Murray & G.S. West, Rec'd 8.12.1911 \\
\hline BM 34117 & Lake W. side of McMurdo Sound, Jan 1909. & Coll. R.E. Priestley & G.S. West, Rec'd 8.12.1911 \\
\hline BM 34118 & Lake W. side of McMurdo Sound, Jan 1909. & Coll. R.E. Priestley & G.S. West, Rec'd 8.12.1911 \\
\hline BM 34119 & Lake W. side of McMurdo Sound, Jan 1909. & Coll. R.E. Priestley & G.S. West, Rec'd 8.12.1911 \\
\hline BM 34120 & Moraine, Mt. Erebus. & $?$ & G.S. West, Rec'd 8.12.1911 \\
\hline BM 34121 & Clear Lake, Cape Royds & Coll. J. Murray & G.S. West, Rec'd 8.12.1911 \\
\hline BM 34122 & Clear Lake, Cape Royds & Coll. J. Murray & G.S. West, Rec'd 8.12.1911 \\
\hline BM 34123 & Dried up Lake, Cape Royds. & ? & G.S. West, Rec'd 8.12.1911 \\
\hline BM 34124 & Moraine, Mt. Erebus. & ? & G.S. West, Rec'd 8.12.1911 \\
\hline BM 34125 & Pony Lake, Cape Royds & Coll. J. Murray & G.S. West, Rec'd 8.12.1911 \\
\hline BM 34126 & Moraine, Mt. Erebus. & $?$ & G.S. West, Rec'd 8.12.1911 \\
\hline BM 34127 & Cape Royds, Ross Island. & ? & G.S. West? \\
\hline BM 34128 & Clear Lake, Cape Royds & Coll. J. Murray & G.S. West, Rec'd 8.12.1911 \\
\hline BM 34129 & Pond, Cape Royds. & Coll. J. Murray & G.S. West, Rec'd 8.12.1911 \\
\hline BM 34130 & Pond, Cape Royds. & Coll. J. Murray & G.S. West, Rec'd 8.12.1911 \\
\hline BM 34131 & Green Lake, Cape Royds & Coll. J. Murray & G.S. West, Rec'd 8.12.1911 \\
\hline BM 34132 & Green Lake, Cape Royds & Coll. J. Murray & G.S. West, Rec'd 8.12.1911 \\
\hline BM 34202 & Pony Lake, Cape Royds & Coll. J. Murray & G.S. West, Rec'd 21.5.1920 \\
\hline BM 34228 & $\begin{array}{l}\text { Brit. Antarctica Expediton (Terra Nova), } \\
\text { 1910, Cape Adare. }\end{array}$ & Fritsch slide & \\
\hline BM 34229 & $\begin{array}{l}\text { Brit. Antarctica Expediton (Terra Nova), } \\
\text { 1910, Cape Adare. }\end{array}$ & Fritsch slide & \\
\hline
\end{tabular}


Table 2. List of recent samples used for the Scanning Electron Microscopy analysis.

\begin{tabular}{lllll}
\hline Sample ID & sampling date & sample location & habitat & published in \\
\hline BH11 & January 2000 & Bunger Hills, East-Antarctica & microbial mat & Gibson et al. (2006) \\
BH14 & January 2000 & Bunger Hills, East-Antarctica & microbial mat & Gibson et al. (2006) \\
C14-77-1B & 1977 & $\begin{array}{l}\text { Taylor Valley, Victorialand, Ant- sediment core } \\
\text { arctica }\end{array}$ & Kellogg et al. (1980) \\
Lake LA9 & 2009 & Langhovede & microbial mat & unpublished \\
\hline
\end{tabular}

and centrifugation ( 3 times 10 minutes at $3500 \mathrm{rpm}$ ), the material was diluted with distilled water to avoid excessive concentrations of diatom valves that may hinder reliable observations. Cleaned diatom valves were mounted in Naphrax $^{\circledR}$. LM observations were conducted using an Olympus BX51 microscope equipped with Differential Interference Contrast (Nomarski) optics. For SEM, part of the suspension was filtered through polycarbonate membrane filters with a pore diameter of $3 \mu \mathrm{m}$, pieces of which were fixed on aluminium stubs after air-drying. The stubs were sputter-coated with $50 \mathrm{~nm}$ of $\mathrm{Au}$ and studied in a JEOL-5800LV at $20 \mathrm{kV}$.

Terminology of frustule morphology is based on Hendey (1964), BARBER \& HAWORTH (1981) and Round et al. (1990). Samples and slides from the Bunger Hills and Taylor Valley are stored at the National Botanic Garden of Belgium (BR), Department of Bryophytes and Thallophytes.

\section{Observations and Discussion}

In their original publication, WeST \& WEST (1911) reported 30 diatom taxa belonging to (following the taxonomical concepts of that time) 16 genera. Eight species and two varieties were described as new for science. Table 3 lists all 30 species with their current taxonomic identity and/or status.

Several taxa such as Navicula (Pinnularia) globiceps Gregory, Stauroneis anceps EHRENBERG and Achnanthes brevipes var. intermedia (KüTZING) Cleve were illustrated but wrongly identified in WeST \& WeST and later described as new species by other authors, viz. Luticola gaussii (HEIDEN) D.G. Mann (Heiden \& Kolbe 1928), Stauroneis latistauros VAN DE VIJVER ET LANGE-BerTalot (VAN DE VIJVER et al. 2004), and Achnanthes taylorensis Kellogg et Kellogg (Kellogg et al. 1980) respectively. For all other taxa listed in WEST \& WeST (1911), no illustrations or descriptions were provided, making it sometimes impossible to verify their identity, as they were apparently quite rare in the samples and could not be found during a re-examination of the slides. Finally, a considerable portion of the reported species has a marine origin, e.g. Trachyneis aspera (EHRENBERG) Cleve, Triceratium arcticum BRIGHTwell or Hemiaulus ambiguus JANISCH.

Based on our re-analysis of the original WeSt \& West material, it is clear that two Antarctic taxa, which to date have been wrongly identified and/or force-fitted to species described by WeST \& WeST, actually constitute species in their own right. One of these is usually identified as Navicula murrayi W. et G.S. WeST and is here described as Luticola pseudomurrayi VAN DE VIJVER et TAVERNIER sp. nov. A second taxon resembles Chamaepinnularia cymatopleura and is described here as Chamaepinnularia gibsonii VAN DE VIJVER sp. nov.

Species newly described by W. \& G.S. WEST (1911)

Chamaepinnularia cymatopleura (W. et G.S. West) CavaCini (Figs 1-23)

Basionym: Navicula (Pinnularia) cymatopleura W. et G.S. WEST

Original description (WeSt \& WeSt 1911): Navicula minutissima, valves sublinearis, diametro $4^{1 / 4}-5$ 2/5-plo longioribus, lateribus triundulatis, undulo mediana levissime majori, polis subcapitatis, platea centrali magna et longitudinaliter elliptica, platea axiali lata, striis brevibus et laevibus, 20-21 in $10 \mu \mathrm{m}$, leviter radiates in parte mediana (adversus plateam centralem). Longitudo 17-27 $\mu \mathrm{m}$, latitudo 4-5 $\mu \mathrm{m}$.

Translation of the original description: very small Navicula, sublinear valves, $41 / 4-52 / 5$-fold longer than wide. Margins triundulate, the middle undulation slightly larger. Apices subcapitate. Central area large and apically elliptical. Axial area broad. Striae short and smooth, 20-21 in 10 $\mu \mathrm{m}$, slightly radiate in the middle part of the valve 
Table 3. List of diatom species reported in WeST \& WeST (1911).

\begin{tabular}{|c|c|c|}
\hline Name published in West \& West (1911) & current name (if changed) & Habitat \\
\hline $\begin{array}{l}\text { Achnanthes brevipes AG. var. Intermedia (KüTZ.) } \\
\text { CLEVE }\end{array}$ & Achnanthes taylorensis KELLOGG et al. & $\mathrm{M}$ \\
\hline Cocconeis litigiosa $\mathrm{V}$. HeURCK & & M \\
\hline Cocconema pusilla (GRUN.) nob. & Seminavis pusilla (Grun.) E.J. Cox et G. ReID & M \\
\hline Coscinodiscus lentiginosus JAN. & Thalassiosira lentiginosa (JAN.) FRYXELL & M \\
\hline Fragilaria obliquecostata V. HeURCK & $\begin{array}{l}\text { Fragilariopsis obliquecostata (V. HeURCK) HE- } \\
\text { IDEN et KOLBE }\end{array}$ & M \\
\hline $\begin{array}{l}\text { Fragilaria tenuicollis HeIB. var. antarctica W. et } \\
\text { G.S. WEST }\end{array}$ & Nitzschia westiorum Kellog et Kellog & $\mathrm{F}$ \\
\hline Hantzschia amphioxys (EHR.) GRUN. & & $\mathrm{F}$ \\
\hline Hantzschia elongata (HANTZSCH) GRUN. & & $\mathrm{F}$ \\
\hline Hemiaulus ambiguus JAN. & & M \\
\hline Melosira distans (ЕнR.) KÜTz. & Aulacoseira distans (EHR.) SIMONSEN & $\mathrm{F}$ \\
\hline Melosira varians Ag. & & $\mathrm{F}$ \\
\hline $\begin{array}{l}\text { Navicula (Pinnularia) cymatopleura W. et G.S. } \\
\text { WEST }\end{array}$ & $\begin{array}{l}\text { Chamaepinnularia cymatopleura (W. et G.S. } \\
\text { WEST) CAVACINI }\end{array}$ & $\mathrm{F}$ \\
\hline Navicula (Pinnularia) globiceps GREG. & Luticola gaussii (HEIDEN) D.G. MANN & $\mathrm{F}$ \\
\hline $\begin{array}{l}\text { Navicula (Pinnularia) murrayi var. elegans W. et } \\
\text { G.S. WEST }\end{array}$ & Luticola murrayi (W. et G.S. WEST) D.G. MANN & $\mathrm{F}$ \\
\hline Navicula (Pinnularia) murrayi W. et G.S. WEST & Luticola murrayi (W. et G.S. WEST) D.G. MANN & $\mathrm{F}$ \\
\hline $\begin{array}{l}\text { Navicula (Pinnularia) shackletonii W. et G.S. } \\
\text { WEST }\end{array}$ & Navicula shackletonii W. et G.S. WEST & $\mathrm{F}$ \\
\hline $\begin{array}{l}\text { Navicula (Pinnularia) shackletonii var. pelludica } \\
\text { W. et G.S. WEST }\end{array}$ & Navicula shackletonii W. et G.S. WEST & \\
\hline Navicula glaberrima W. et G.S. West & & $\mathrm{F}$ \\
\hline Navicula muticopsiforme W. et G.S. WEST & & $\mathrm{F}$ \\
\hline $\begin{array}{l}\text { Navicula muticopsis V. HEURCK incl. f. evoluta et } \\
\text { f. reducta }\end{array}$ & Luticola muticopsis (V. HeURCK) D.G. MANN & $\mathrm{F}$ \\
\hline Navicula peraustralis W. et G.S. WEST & $\begin{array}{l}\text { Muelleria peraustralis (W. et G.S. WeSt) SPAULD- } \\
\text { ING et STOERMER }\end{array}$ & $\mathrm{F}$ \\
\hline Navicula perlepida GRUN. & Caloneis perlepida (GRUN.) A. BERG & M \\
\hline Navicula radiosa KÜTZ. & & $\mathrm{F}$ \\
\hline Navicula rhynchocephala KüTz. & & $\mathrm{F}$ \\
\hline Nitzschia subtilis (KüTz.) GRUN. & & $\mathrm{F}$ \\
\hline Stauroneis anceps EHR. & $\begin{array}{l}\text { Stauroneis latistauros VAN DE VIJVER et LANGE- } \\
\text { BERTALOT }\end{array}$ & $\mathrm{F}$ \\
\hline Surirella angusta KüTz. & & $\mathrm{F}$ \\
\hline Tabellaria flocculosa (Rотн.) KüTz. & & $\mathrm{F}$ \\
\hline Trachyneis aspera (EHR.) CLEVE & & M \\
\hline Triceratium arcticum BRIGHTW. & Biddulphia arctica (BRIGHTw.) BOYER & M \\
\hline Tropidoneis laevissima W. et G.S. WEST & $\begin{array}{l}\text { Craspedostauros laevissimum (W. et G.S. WEST) } \\
\text { SABBE }\end{array}$ & $\mathrm{F}$ \\
\hline
\end{tabular}



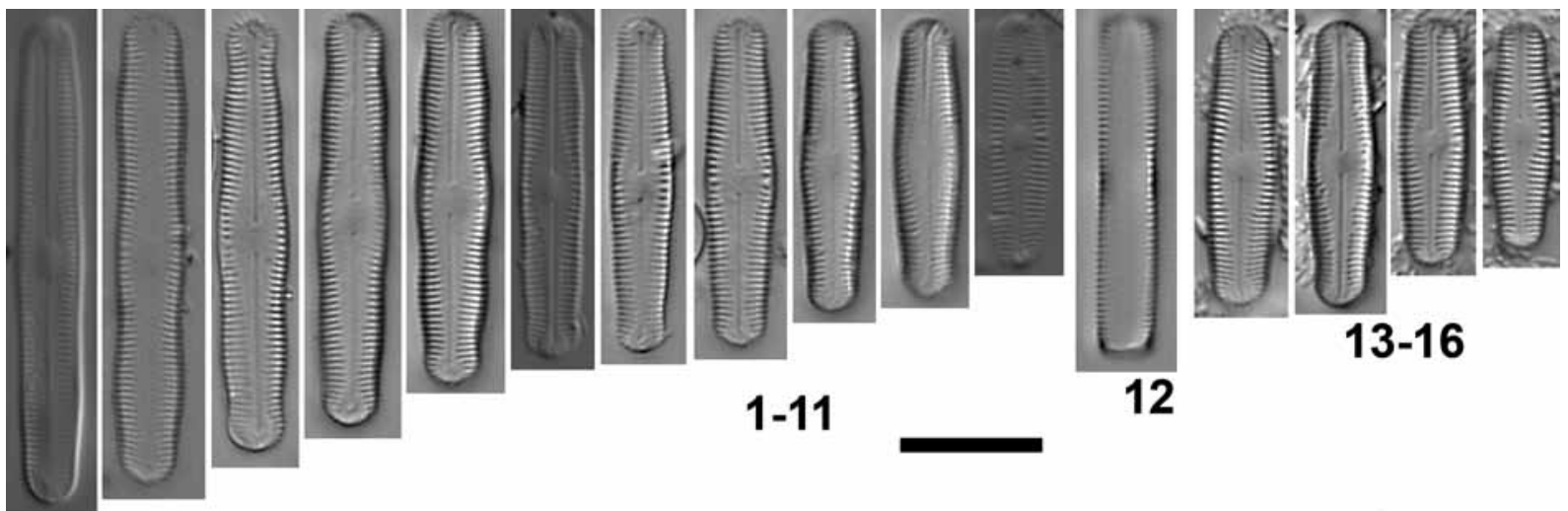

$1-11$

12
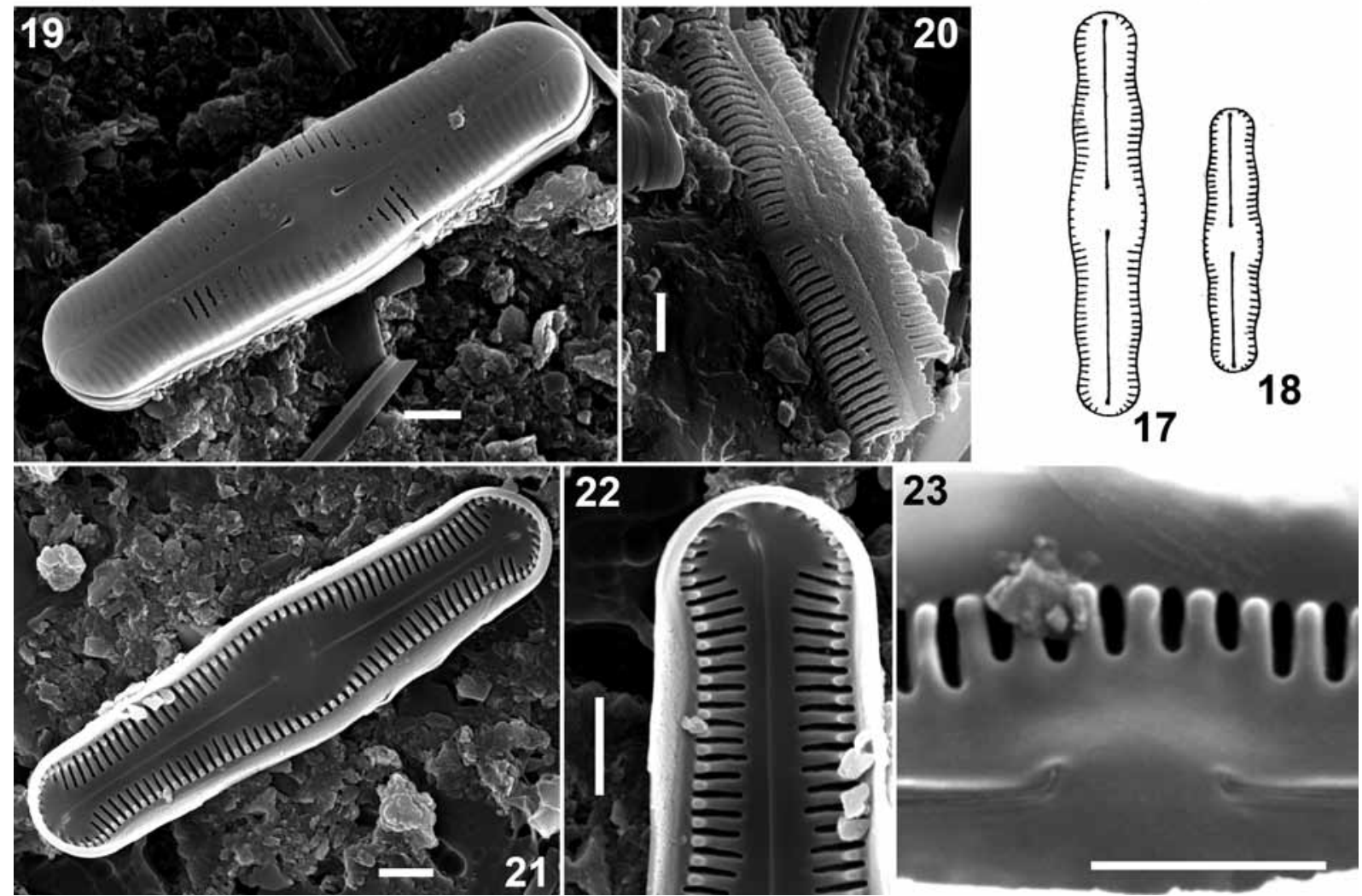

Figs 1-23. Chamaepinnularia cymatopleura: (1-11) light microscopical images of a population present on the original W. \& G.S. West slides; (12) girdle view from the original population; (13-16) LM images of Navicula deltaica and Navicula quaternaria from the type slide C14-77-1; (17-18) original drawings from WEST \& WeST (1911); (19) scanning Electron Microscope (SEM) external view of an entire valve; (20) SEM external view of the central area of an eroded valve. Note the striae running over the valve face/mantle margin; (21) SEM internal view of an entire valve; (22) SEM internal detail of the apex with a small helictoglossa; (23) SEM internal view of the central area. Note the presence of blunt spines on the virgae. Scale bars (1-18) $10 \mu \mathrm{m} ;(19-23) 2 \mu \mathrm{m}$.

(near the central area). Length $17-27 \mu \mathrm{m}$, width 4-5 $\mu \mathrm{m}$.

Lectotype: slide BM34146 (Natural History Museum, London, UK)

Synonyms: Navicula deltaica KellogG et Kellogg in Kellogg et al., Navicula quaternaria Kellogg et Kellogg in Kellogg et al.

LM observations: frustules in girdle view rectangular (Fig. 12). Larger valves linear to linear-elliptical with (tri-)undulate margins and subcapitate apices; smaller specimens more broadly elliptical with a (slightly) convex central part and broadly rounded to slightly rostratecapitate ends (Figs 1-11). Valve length 15-36 $\mu \mathrm{m}$, width 3.6-5.1 $\mu \mathrm{m}(\mathrm{n}=30)$. Axial area wide, lanceolate, with slightly triundulate margins in the larger specimens. Towards the apices, the axial area widens to form a wedge-shaped hyaline area around the terminal raphe fissures. 
Central area lanceolate to elliptical. Raphe straight, filiform with expanded, pore-like central endings and hooked terminal fissures. Transapical striae slightly radiate in the middle, parallel to convergent towards the poles, 20-24 in $10 \mu \mathrm{m}$.

SEM observations (Bunger Hills 11): alveoli covered by hymenes (Fig. 19). When eroded, alveoli slit-like, not interrupted near the valve face/ mantle junction (Fig. 20). Central raphe endings small, expanded, pore-like, almost straight to weakly deflected (Fig. 20). Terminal fissures hooked, continuing on the valve mantle (Fig. 19). Internally, proximal raphe endings short, bent in the same direction (Figs 21, 23). Terminal raphe with small helictoglossae (Fig. 22). Internally, small, blunt, spine-like structures present on the virgae close to the valve face/mantle junction (Fig. 23).

Distribution: Chamaepinnularia cymatopleura is widespread on the Antarctic Continent (see Kellogg \& Kellogg 2002 - as Pinnularia cymatopleura - and references therein; SABBE et al. 2003; CAVACINI et al. 2006). To date there are no confirmed records from the Maritime and Subantarctic Regions.

Taxonomical remarks: CAVACINI et al. (2006) analysed the type material of Navicula (Pinnularia) cymatopleura and concluded that the species should be transferred to Chamaepinnularia, although the alveoli are not interrupted on the valve face/mantle junction contrary to what is claimed (CAVACINI et al. 2006 , pp. 60, 64). While C. cymatopleura is larger than most Chamaepinnularia species, all other features typical for the genus are present, such as the uniseriate striae (contrary to Pinnularia which has multiseriate striae), and therefore the transfer to Chamaepinnularia proposed by CAVACINI et al. (2006) appears to be justified.

Spaulding et al. (1997) and SabBe et al. (2003) synonymized Navicula deltaica and $N$. quaternaria on the basis of their close resemblance to smaller specimens of $C$. cymatopleura. Both species were never validly described because the types of both species were never deposited in the Academy of Natural Sciences of Philadelphia (CAVACINI et al. 2006). We analysed the original materials used by KellogG et al. (1980) and confirm that both taxa belong to the smaller end of the size range of C. cymatopleura (Figs 13-16). During our analyses, an unknown taxon, similar to C. cymatopleura, was found in the Bunger Hills samples. This taxon is described as a new species, Chamaepinnularia gibsonii, below.

Craspedostauros laevissimus (W. et G.S. West) Sabbe (Figs 24-39)

Basionym: Tropidoneis laevissima W. et G.S. WeST Original description (WEST \& WeSt 1911): T. parva, delicatissima et laevissima; valves oblongo-linearis, diametro 8-11-plo longioribus, in parte mediana marginibus parallelibus, apices versus leviter et gradatim angustiaribus, polis obtuse rotundatis, raphe recta sed juxta polos levissime curvata nodulo centrali in staurum transversum producto, stauro angustissimo plerumque valvae margines versus paullulo dilatato, alis (vel carinis) carentibus, striis non visis. Cellulae in aspectu cingulato angusteoblongo-rectangulari, medio constricta, lateribus convexis et angulis rotundatis.

Translation of the original description: Small Tropidoneis species, very delicate and smooth. Valves oblong-linear, 8-11 times longer than wide. Margins parallel in the middle part. Valves gradually narrower towards the apices. Apices obtusely rounded. Raphe straight but near the apices very slightly curved, forming a central nodule in the stauros. Stauros very narrow in most of the valves with very slightly widened valve margins, lacking wings or keels. Striae not visible. Cells in girdle view narrow, oblong-rectangular, constricted in the middle part with convex margins and rounded edges.

Lectotype (here designated): slide BM34122 (Natural History Museum, London, UK)

LM observations: Frustules in girdle view more or less biarcuate (Figs 29-30). Valves linear to linear-lanceolate, sometimes slightly constricted in the centre, with broadly rounded to cuneate apices (Figs 24-28). Margins sometimes irregular, probably due to flattening and rupture of the thin valves. Valve length 35-88 $\mu \mathrm{m}$, width 4.8-7.8 $\mu \mathrm{m}$ $(n=20)$. Axial area narrow, linear. Central area narrow, rectangular to bow tie-shaped. Raphe filiform, straight to slightly undulate, with slightly expanded central raphe endings. Terminal raphe endings bent to the same side, clearly visible in LM. Striae parallel to slightly radiate near the central area, 26-28 in $10 \mu \mathrm{m}$. Areolae not discernible in LM.

SEM morphology (Bunger Hills 14): Areolae rounded, closed externally by cribra with four (or more alongside the raphe sternum) small peripheral pores and occasionally one small central pore (Figs 36, 37). Central raphe endings expanded, 

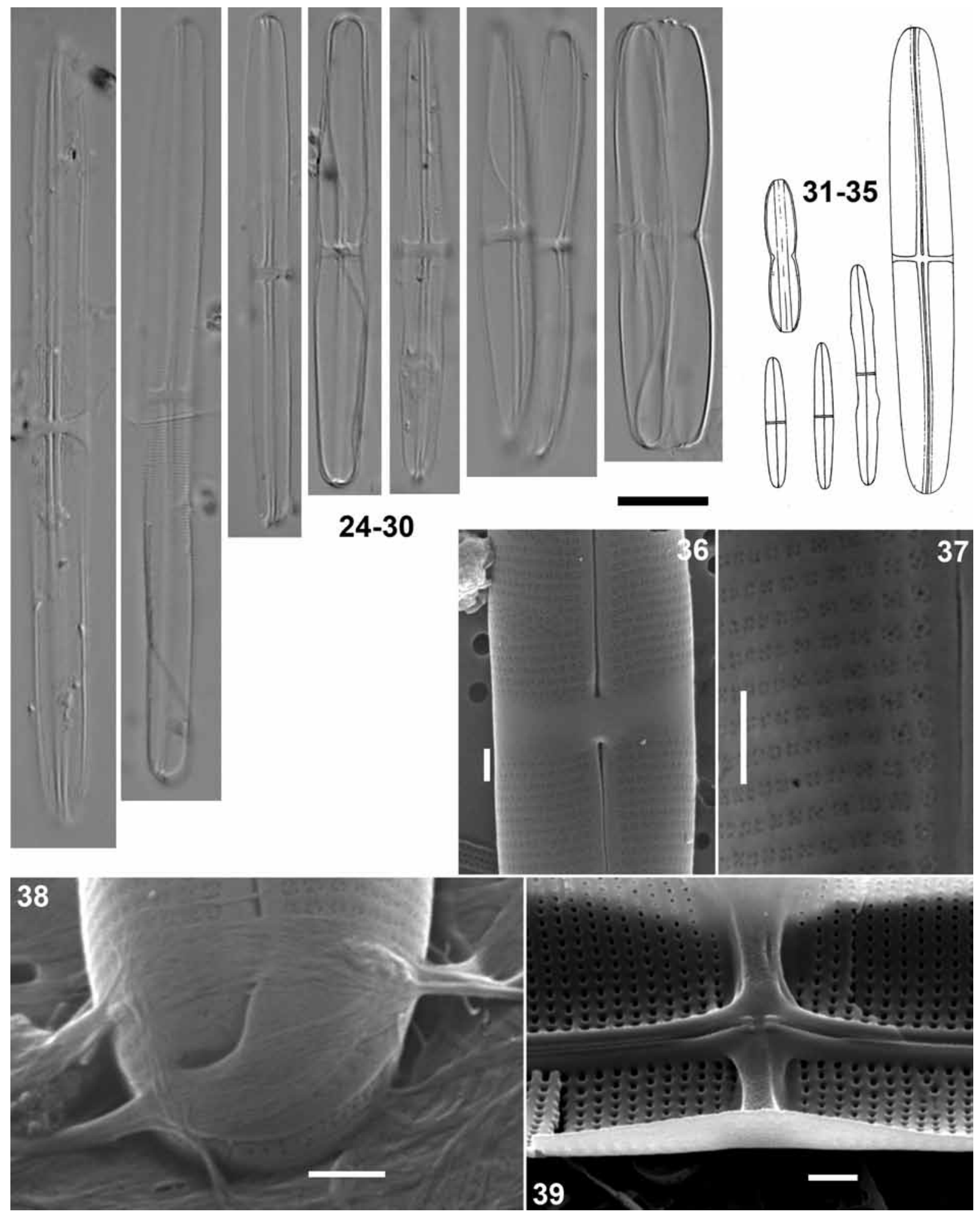

Figs 24-39. Craspedostauros laevissimus: (24-30) light microscopical images of a population present on the original W. \& G.S. West slides; (31-35) original drawings from West \& WeSt (1911); (36) Scanning Electron Microscope (SEM) external view of the central area; (37) SEM external detail of the areola structure; (38) SEM external view of the apex; (39) SEM internal view of the central area. Scale bars (24-35) $10 \mu \mathrm{m}$; (36-39) $1 \mu \mathrm{m}$. 

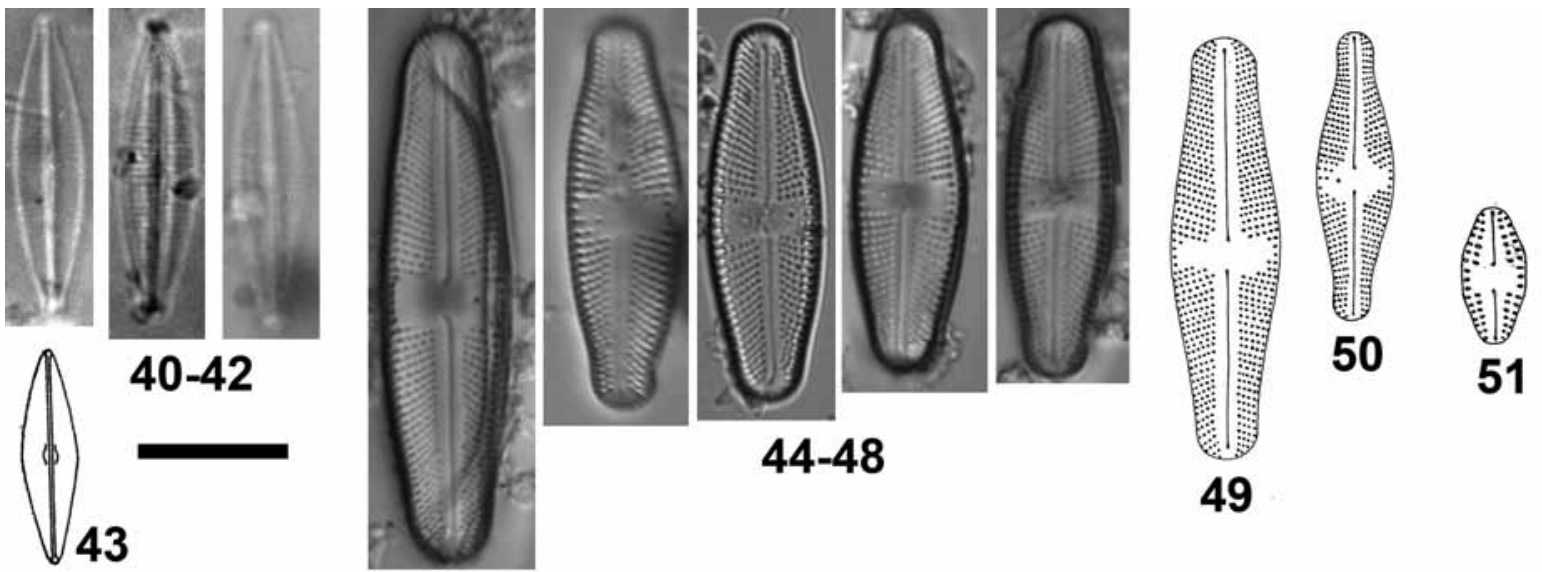

Figs 40-43. Craticula glaberrima: (40-42) light microscopical images of a population present on the original W. \& G.S. West slides; (43) original drawing from WeSt \& WeSt (1911).

Figs 44-50. Luticola murrayi : (44-48) light microscopical images of a population on the Antarctic Continent (photos: courtesy of Dr. Sarah Spaulding); (49) original drawing of Navicula murrayi by WEST \& WeSt (1911); (50) original drawing of Navicula murrayi var. elegans by WeSt \& WeST (1911).

Fig. 51. Navicula muticopsiforme: original drawing by West \& WeST (1911).

straight to weakly deflected (Fig. 36). Terminal fissures clearly bent, terminating on the valve face margin (Fig. 38). Pores continue around the apices. Internally, raphe sternum well-developed, raised (Fig. 39). Central area internally with a narrow stauros lying in a wider hyaline fascia (Fig. 39). Internal central raphe endings terminate in a small double helictoglossa (Fig. 39). Internal areola openings more or less square to rounded.

Distribution: Craspedostauros laevissimus is a widespread endemic species restricted to the Antarctic Continent [Eastern Antarctica and Victoria land (see Kellogg \& Kellogg 2002 - as Tropidoneis laevissima - and references therein; SABBE et al. 2003)]. The species has never been observed outside continental Antarctica.

Taxonomical remarks: Craspedostauros laevissimus can be found under different names in the Antarctic literature. The species was originally placed in the genus Tropidoneis. PAtrick \& ReImer (1975) rejected the genus Tropidoneis and included all its species in the genus Plagiotropis which has priority. It is clear that $C$. laevissimus does not belong to the latter genus, which has a different areolar structure without cribra and a different internal raphe structure, without central helictoglossae. While PADDOCK (1988), without studying material of $C$. laevissimus, suggested that the species might belong to Stauroneis, it was finally transferred to the new genus Craspedostauros (CoX 1999) in SABBE et al.
(2003) on the basis of areolar, raphe and cingulum structure.

\section{Navicula glaberrima W. et G.S. WEST (Figs 40-} 43)

Original description (WeSt \& WeSt 1911): Navicula minutissima et laevissima; valvis rhomboideis vel rhomboideo-ellipticis cum lateribus paene rectis, polis levissime rotundatis, raphe rectissima, nodulis terminalibus conspicuis, striis non visis. Longitudo valvae $19 \mu \mathrm{m}$, latitudo $5.1 \mu \mathrm{m}$.

Translation of the original description: very small and smooth Navicula. Valves rhomboid to rhomboid-elliptic with almost straight margins and very slightly rounded apices. Raphe very straight with distinct terminal nodules. Striae not visible. Valve length $19 \mu \mathrm{m}$, with $5.1 \mu \mathrm{m}$.

Lectotype (here designated): slide BM34117 (Natural History Museum, London, UK).

LM observations: valves lanceolate to rhombiclanceolate, apices sub-rostrate to rostrate (Figs 40-42). Valve length 19-20 $\mu \mathrm{m}$, width 4.9-5.1 $\mu \mathrm{m}$ $(n=2)$. Axial area very narrow, linear, central area absent. Raphe filiform with straight, expanded central pores. Terminal fissures not visible in LM. Transapical striae parallel to weakly radiate throughout the entire valve, ca. 22 in $10 \mu \mathrm{m}$. Areolae not visible in LM.

SEM observations: so far, the only record of this species has been in the WeST \& WeST (1911) publication. It has been impossible to find other 

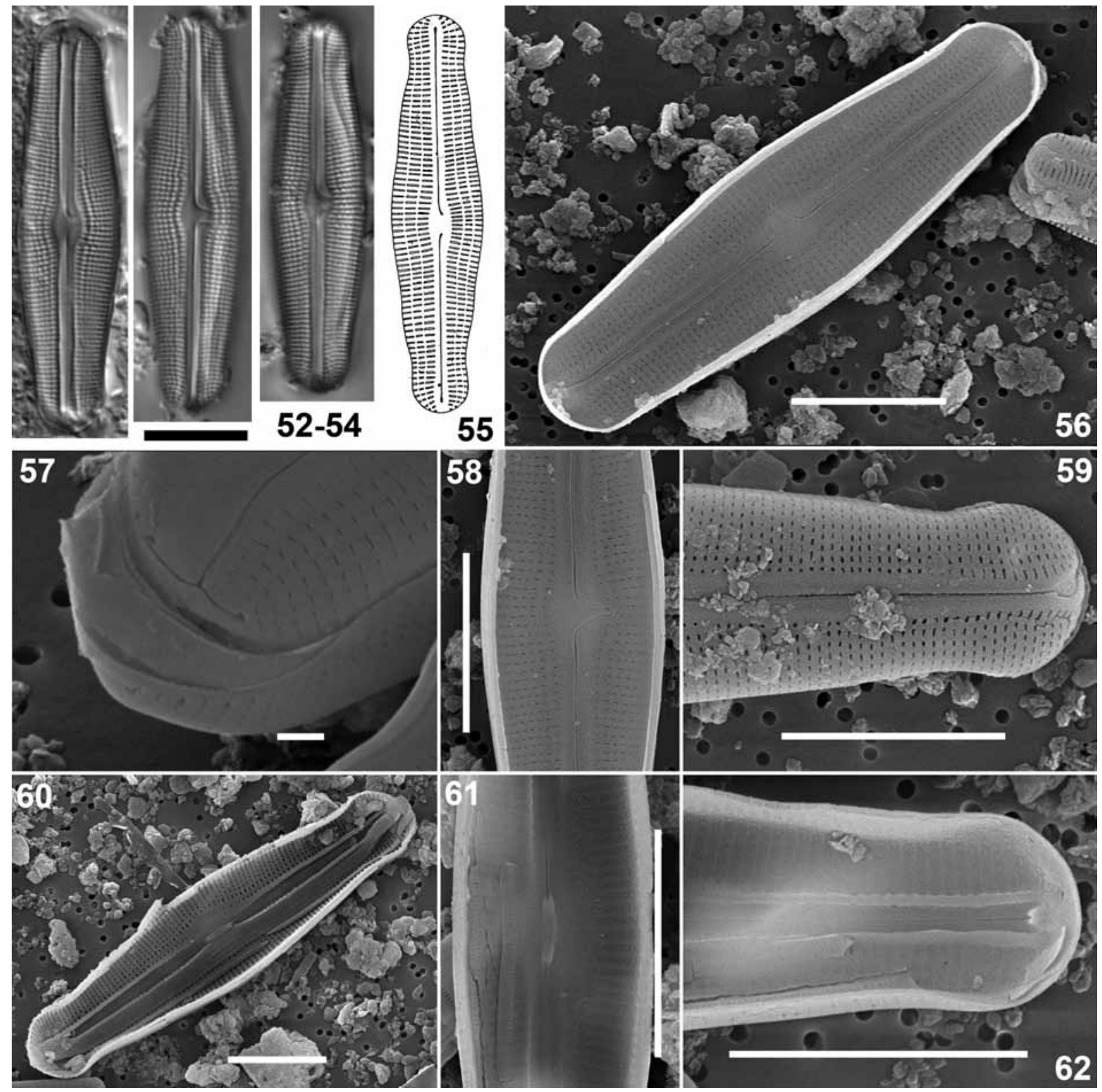

Figs 52-62. Muelleria peraustralis : (52-54) light microscopical images of a population present on the original W. \& G.S. West slides; (55) original drawings by WeST \& WeST (1911); (56) Scanning Electron Microscope (SEM) external view of an entire valve; (57) SEM external view of the apex with the bifurcating terminal raphe fissure and the presence of canal puncta; (58) SEM external view of the central area; (59) SEM external view of the areolae; (60) SEM internal view of an entire valve; (61) SEM internal view of the central area with the rectelevatum; (62) SEM internal view of the apex showing the longitudinal canals and the helictoglossa. Scale bars (52-56, 58-62) $10 \mu \mathrm{m}$; (57) $1 \mu \mathrm{m}$.

samples containing $N$. glaberrima. Therefore, no SEM observations could yet be made.

Distribution: the species has so far only been found in a large lake on the west side of McMurdo Sound, at 25 miles from the Cape Royds Camp (7745’S) (WEST \& WeSt 1911).

Taxonomical remarks: $N$. glaberrima most probably does not belong to the genus Navicula s.s. but resembles several members of the genus
Craticula (Lange-Bertalot 2001). Since only two valves could have been investigated in LM, it is probably too early to draw conclusions about its taxonomic status. It is possible that $N$. glaberrima is conspecific to $C$. submolesta (HUSTEDT) LANGEBERTALOT based on valve outline, dimensions and stria density and hence represents a younger synonym of the latter. Craticula submolesta has never been observed on the Antarctic Continent (Kellogg \& Kellogg 2002) although it was reported from the South Shetland Islands 

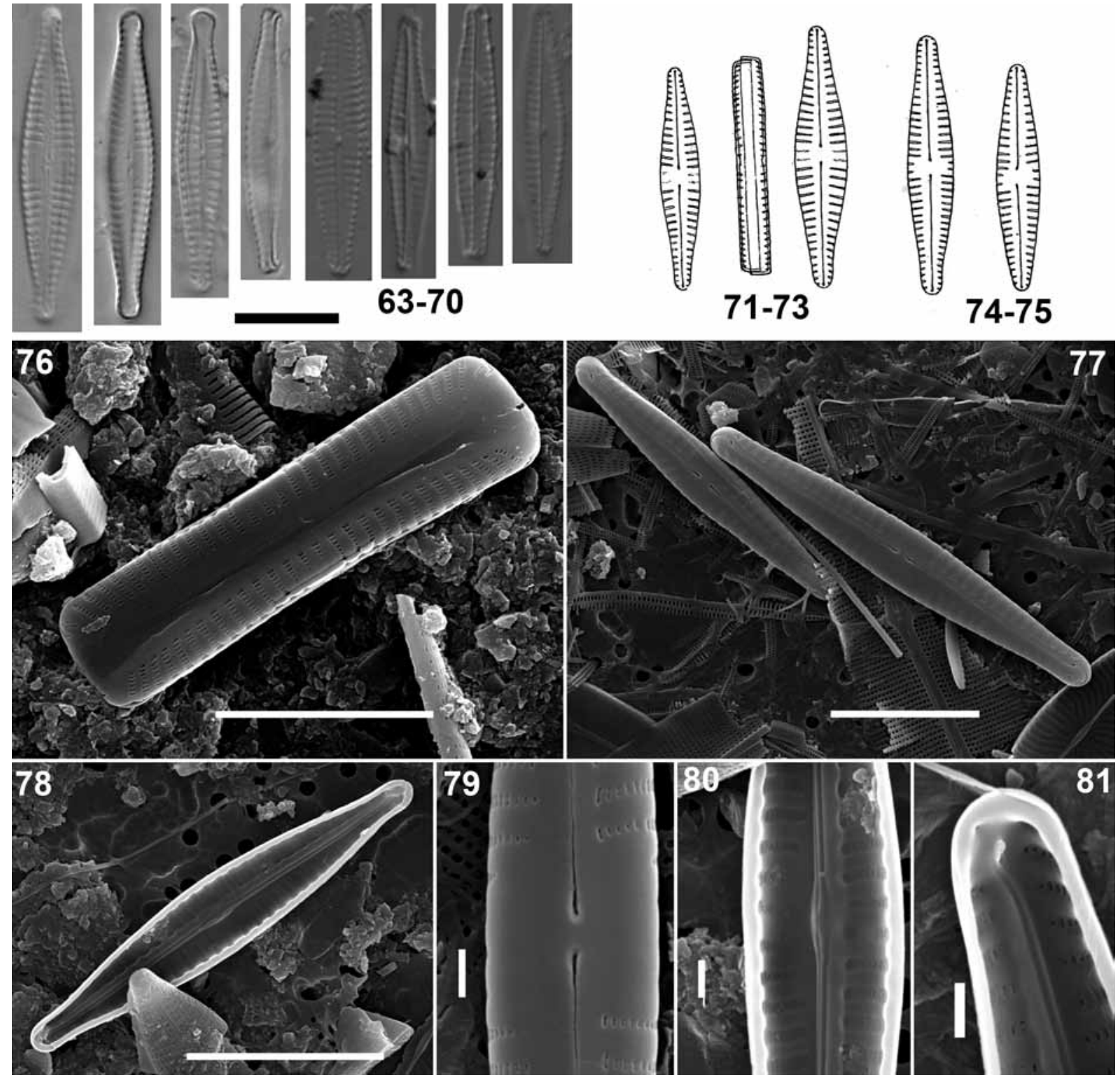

Figs 63-81. Navicula shackletoni: (63-70) light microscopical images of a population present on the original W. \& G.S. West slides; (71-73) original drawings of Navicula shackletoni by WeST \& WEST (1911); (74-75) original drawings of Navicula shackletoni var. pellucida by WEST \& WEST (1911). Fig. 76. Scanning Electron Microscope (SEM) external view of an entire frustule in girdle view; (77) SEM external view of two entire valves; (78) SEM internal view of an entire valve; (79) SEM external view of the central area; (80) SEM internal view of the central area; (81) SEM internal view of the apex with the helictoglossa. Scale bars (63-78) $10 \mu \mathrm{m}$; (79-81) $1 \mu \mathrm{m}$.

(HǍKANSSON \& JoNES 1994) and Horseshoe Island (WASEll \& HÅkansson 1992; Wasell 1993). On the Antarctic Continent, a second Craticula species has been regularly found in larger populations than $N$. glaberrima. The species has been for a long time identified as Craticula (Navicula) molesta (Krasske) Lange-Bertalot et Willmann, a species described in 1938 from Spitsbergen by G. Krasske (or as Navicula zizix VAN LANDINGHAM as it was called later). Recently, the morphology of the species was thoroughly investigated and based on the results, it was described as a separate species,
Craticula antarctica Van de Vijver et Sabbe (Van DE VIJVER et al. 2010). Possible conspecificity between $N$. glaberrima and $C$. antarctica has to be excluded based on differences in valve outline and dimensions.

\section{Luticola murrayi (W. et G.S. WEST) D.G. MANN} (Figs 44-50)

Basionym: Navicula (Pinnularia) murrayi W. et G.S. WEST

Original description (West \& West 1911): Navicula parva, lineari-ellipticis, diametro circiter 4-plo 
longioribus, polis obtusis laevissime dilatatis, platea centrali transverse expansa, marginem utrinque paene attingente cum puncta solitaria asymmetrica, platea axiali angusta, striis 14 in $10 \mu \mathrm{m}$, punctulatis, in toto radiates, in parte mediana 4 (circ.) utrobique multe brevioribus.

Translation of the original description: small Navicula. Valves linear-elliptical, four times longer than wide. Apices obtuse, very slightly widened. Central area transversely expanded, almost reaching the margins on both sides with an asymmetrical solitary puncta. Axial area narrow. Striae 14 in $10 \mu \mathrm{m}$, punctate, radiate throughout the entire valve. In the middle part of the valve, 4 shorter striae present on both sides.

Lectotype (here designated): slide BM34129 (Natural History Museum, London, UK)

Synonyms: Navicula muticopsis f. murrayi (W. et G.S. West) Ko-BAyAshi, Luticola laeta SPAULDING et Esposito, L. murrayi var elegans W. et G.S. WEST.

LM observations: valves elongated, linearlanceolate to narrowly elliptical with broadly rounded to rostrate-capitate apices (Figs 44-48). Valve length 20-45 $\mu \mathrm{m}$, width 8-11 $\mu \mathrm{m}(\mathrm{n}=5)$. Axial area rather broad, linear. Central area forming a rectangular fascia. Isolated stigma present, positioned about halfway between the valve margin and the axial area. Raphe straight, filiform; central raphe endings simple, deflected in the same direction, away from the stigma. Terminal raphe fissures short, bent in the same direction as the central raphe endings, lying in a hyaline area near the apices. Transapical striae radiate throughout the entire valve, $14-18$ in 10 $\mu \mathrm{m}$. Striae clearly punctate, composed of 4-7 small areolae.

SEM observations: due to the extreme rarity of the species in the investigated samples, we were as yet unable to observe it in SEM.

Distribution: because of the confused identity of this species (see below), most published reports are unreliable and its exact geographic distribution remains unclear. To date, L. murrayi has only been reported with certainty from the type locality ('in pond, and moraines near camp, Cape Royds' on Ross Island) and various localities in the McMurdo Dry Valleys (based on the illustrations shown on the Antarctic Freshwater Diatoms website Spaulding et al. 2011).
Taxonomical remarks: No specimens matching the original type description and drawing (West \& West 1911, PIXXVI, Fig. 129, reproduced here as Fig. 49) could be found in the West \& West materials. In other samples from the McMurdo Dry Valleys, we did find some specimens (Figs 44-48, see also SpaULDING et al. 2011) matching the valve shape and the lower range of the stria density (as shown in the type illustration and description) and possessing a stigma (as described in the protologue, but not shown in the type illustration!). Despite the fact that in our specimens the stria density range was considerably larger (14-18 striae in $10 \mu \mathrm{m}$ ), we believe that these specimens should be considered true L. murrayi, as the differences in stria density range may be due to the fact that WeSt \& WEST (1911) probably only saw a single specimen. The fact that the stigma is mentioned in the type description but not shown in the accompanying illustration also leads us to believe that the drawing is inaccurate (note also that the central raphe endings are shown as being straight). The identity of $L$. murrayi has been confused in several taxonomic treatments. This confusion is likely traced to the studies of KoBaYashi (1963) and Hustedt (1961-1966). Both authors discuss the morphology and variability of $L$. murrayi but show specimens with distinctly capitate, wide apices, while according to the original protologue the apices are obtuse ('obtusis') and only very slightly expanded ('laevissime dilatatis'). The taxon illustrated by KOBAYASHI (1963) and Hustedt (1961-1966) is therefore described as a new species below, viz. Luticola pseudomurrayi VAN DE VIJVER et TAVERNIER sp. nov. The case of Luticola murrayi thus presents a classic example of taxonomic drift. Due to this confusion, published reports of this species are not trustworthy.

Our 'new' concept of $L$. murrayi largely overlaps with the description of L. laeta, which was described by Esposito et al. (2008). The latter taxon is most probably a later synonym of $L$. murrayi, but due to the rarity of $L$. murrayi we still refrain from formally synonymising $L$. laeta with $L$. murrayi until further populations can be analyzed. Note that West \& West also described a new variety belonging to this species, viz. $N$. murrayi var. elegans, which is smaller, narrower, and has produced subcapitate apices (West \& West 1911, PIXXVI, Fig. 130, reproduced here as Fig. 50). This specimen (apparently here as well has only one specimen been observed) matches the description of $L$. laeta even better, but may also 
fall within the range of L. murrayi.

Muelleria peraustralis (W. et G.S. WEST) Spaulding et Stoermer (Figs 52-62)

Basionym: Navicula peraustralis W. et G.S. WEST Original description (WEST \& WeST 1911): Navicula parva, valves anguste lineari-lanceolatis, diametro circiter 4 1/3-plo longioribus, lateribus triundulatis inflatione mediana majori, polis inflato-capitatis et levissima angularibus, platea centrali parva et elliptica, platea axiali angusta, striis validis 18 in $10 \mu \mathrm{m}$, leviter radiates, a plateis lateralibus duobus interruptis. Longitudo $47.7 \mu \mathrm{m}$, latitudo 11,1 $\mu \mathrm{m}$.

Translation of the original description: small Navicula. Valves narrowly linear-lanceolate, 4 $1 / 3$ times longer than wide. Margins triundulate with the largest thickening in the middle. Apices inflated, capitate and very slightly angled. Central area small, elliptical. Axial area narrow. Striae robust, 18 in $10 \mu \mathrm{m}$, slightly radiate, interrupted by two hyaline zones. Length $47.7 \mu \mathrm{m}$, width 11.1 $\mu \mathrm{m}$.

Lectotype (here designated): slide BM34127 (Natural History Museum, London, UK)

LM observations: valves elliptical with a gibbous central part and produced broadly rounded to slightly rostrate-capitate ends (Figs 52-54). Valve face/mantle margin gently sloping into a rather deep mantle. Valve length 30-65 $\mu \mathrm{m}$, width 7.5-12.5 $\mu \mathrm{m}(\mathrm{n}=15)$. Axial area narrow, linear, only slightly widening towards an elliptical central area. Raphe filiform with distant central raphe endings, deflected in the same direction, sometimes reaching the areolae. Terminal raphe endings deflected in the same direction as the central raphe endings. Transapical striae radiate near the valve centre, becoming parallel and convergent towards the apices, 20-21 in $10 \mu \mathrm{m}$ at the valve centre, $22-24$ in $10 \mu \mathrm{m}$ towards the apices. Areolae clearly discernible in LM.

SEM observations (Taylor Valley, C14-77-1B): Striae composed of small, transapically elongated areolae (Figs 56, 58, 59). The row of areolae adjacent to the raphe sternum is often separated from the next longitudinal row by slightly wider vimines (Figs 56, 58). Internally, this longitudinal hyaline band corresponds to longitudinal canals on both sides of the raphe sternum (Fig. 60). Near the terminal raphe endings, the canals end externally in two puncta on the mantle (Fig. 57). Internally, a well-developed rectelevatum (VAN DE VIJVER et al. 2010) is present in the central area (Fig. 61).
Areolae occluded by vela (Fig. 62).

Distribution: Muelleria peraustralis has only been observed on the Antarctic Continent where it is found commonly in East-Antarctica and Victorialand (Spaulding \& Stoermer 1997; Spaulding et al. 1999). No record exists in the Maritime Antarctic Region or the Subantarctic islands where in similar habitats other Muelleria species are found (VAN DE VIJVER et al. 2010).

Taxonomical remarks: Muelleria peraustralis was transferred to the genus Muelleria (SPAULdiNG \& StOERMER 1997) on the basis of typical Muelleria features such as the canal puncta, rectelevatum, strongly bent central raphe endings and a stria structure with more widely spaced striae around the central area (VAN DE VIJVER et al. 2010).

\section{Navicula muticopsiforme W. et G.S. WEST (Fig.} 51)

Original description (WeSt \& West 1911): Navicula minutissima, valves subellipticis, diametro circiter duplolongioribus, partemediana parva cum marginibus parallelis, polis longe cuneiformis et obtuse rotundatis, platea centrali magna et transverse dilatata, platea axiali lata, striis 17 utrobique (16 in $10 \mu \mathrm{m})$, punctatis, in parte mediana (adversus plateam centralem) striis tribus brevibus e puncto singulo elliptico formatis, ceteris radiates e punctis duobus formatis. Longitudo $11.3 \mu \mathrm{m}$, latitudo $5.3 \mu \mathrm{m}$.

Translation of the original description: very small Navicula, valves subelliptical, length almost twice the width, middle part of the valve small with parallel margins, apices elongated, cuneate and obtusely rounded, central area large and transversely widened, axial area broad, 17 striae on both sides (16 in $10 \mu \mathrm{m}$ ), punctate, in the middle part (opposite the central area) three short striae formed of only one single rounded pore, the other striae radiate, composed of two pores. Length $11.3 \mu \mathrm{m}$, width $5.3 \mu \mathrm{m}$.

Taxonomical remarks: we were not able to find any specimens matching the protologue in the material from Clear Lake, the type locality mentioned by WEST \& WEST (1911). Several valves with a similar outline were observed but these had a different central area and striae composed of at least 2-3 areolae. It is possible, considering the fact that only one measurement was given for both length and width, that the description was based on only a single specimen. 

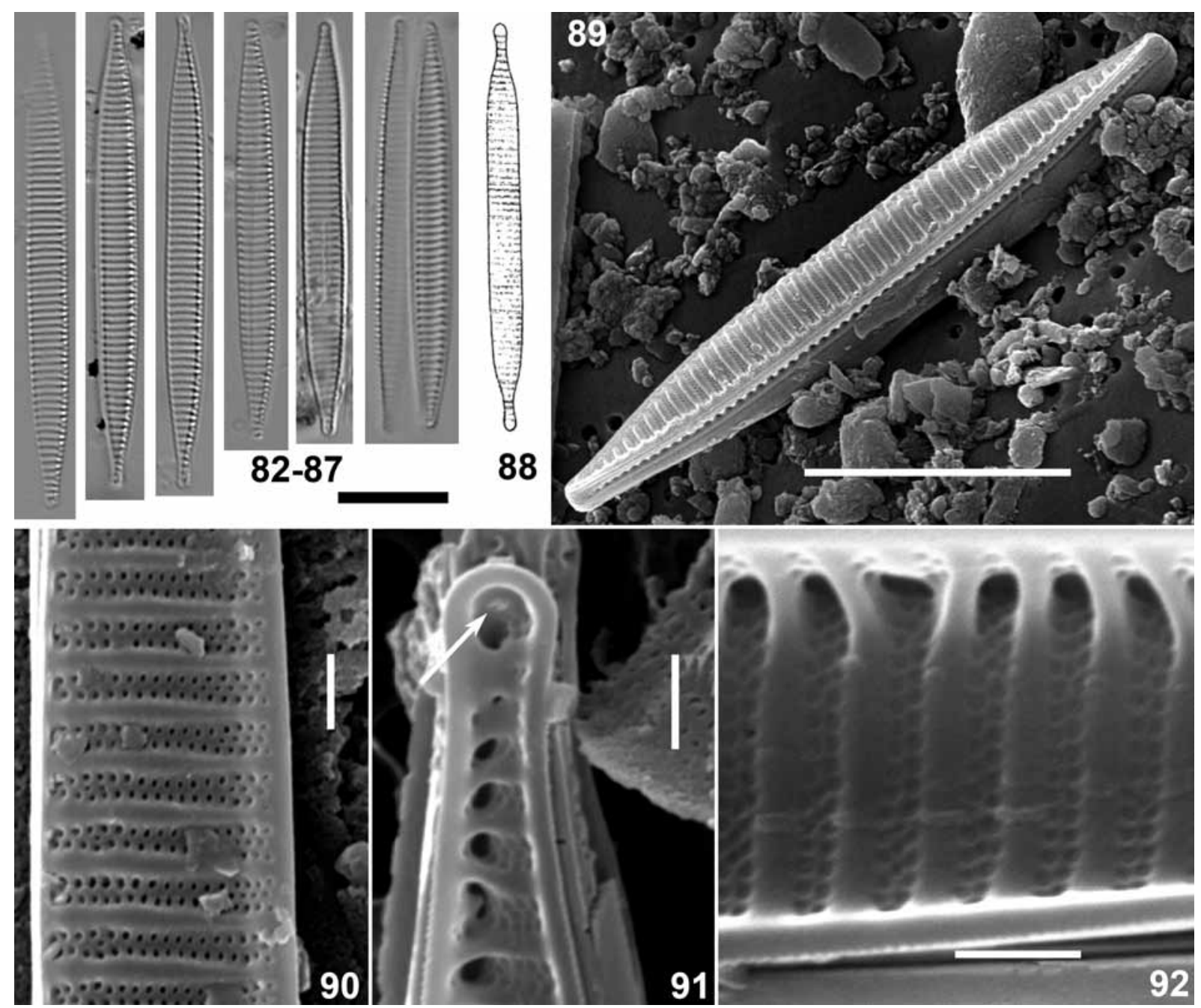

Figs 82-92. Nitzschia westiorum: (82-87) light microscopical images of a population present on the original W. \& G.S. West slides; (88) original drawings of Fragilaria tenuicollis var. antarctica by WeST \& WeST (1911); (89) Scanning Electron Microscope (SEM) external view of an entire valve; (90) SEM external detail of the striae with 2-3 rows of areolae; (91) SEM internal view of the valve apex with the helictoglossa; (92) SEM internal view of the striae showing the absence of fibulae. Scale bars (82-89) $10 \mu \mathrm{m}$; (90-92) $1 \mu \mathrm{m}$.

In material studied by FrITSCH (1917) collected during the British Antarctic Expedition of 1910 from Cape Adare, the species was also reported. Careful examination however of that slide also did not reveal any specimens (although the name was written on the label). On the contrary, many valves could be identified as Luticola muticopsis f. reducta and f. evoluta .

In more recent years, the species was only mentioned once in fossil material from McMurdo Sound (Kellogg \& Kellogg 1987).

Hustedt (1966) considered N. muticopsiforme as part of the size reduction cycle of Luticola (Navicula) muticopsis, reducing the taxon to a synonym of the latter. Based on our analysis of both the original WeSt \& WeST (1911) slide and the FrITSCH (1917) slide, this is probably a correct interpretation and until populations matching the description of $N$. muticopsiforme are observed on the Antarctic Continent, we suggest accepting this hypothesis.

\section{Navicula shackletoni W. et G.S. WeSt (Figs 63-81) \\ Original description (West \& West 1911): Navicula minuta, valvis anguste elliptico-lanceolatis cum polis valde productis levissime subcapitatis et obtusis, platea centrali minuta, platea axiali angustissima, striis 10-12 in $10 \mu \mathrm{m}$, leviter radiatis, validis et non punctulatis, in medio striis duobus utrobique adversus plateam centralem delicatissimis et valde indistinctis. Cellula in aspectu cingulato anguste lineari-oblonga. Longitudo 25-29 $\mu \mathrm{m}$, latitudo 4-5 $\mu \mathrm{m}$.}

Translation of the original description: Small 
Navicula. Valves narrowly elliptic-lanceolate with strongly produced, obtusely rounded, slightly subcapitate apices. Central area small. Axial area very narrow. Striae $10-12$ in $10 \mu \mathrm{m}$, slightly radiate, robust but not punctate. In the middle, two very small, almost indistinct striae present on both sides of the central area. Cells in girdle view narrowly linear-oblong. Length $25-29 \mu \mathrm{m}$, width 4-5 $\mu \mathrm{m}$.

Lectotype (here designated): slide BM34128 (Natural History Museum, London, UK)

LM morphology: frustules rectangular in girdle view (Fig. 72). Valves lanceolate with rostrate to capitate apices (Figs 63-70). Valve length 20-38 $\mu \mathrm{m}$, width 3.8-5.8 $\mu \mathrm{m}(\mathrm{n}=24)$. Axial area narrow, linear, gradually widening towards the central area. Central area forming a rectangular fascia bordered by $2-3$ shortened striae. Raphe filiform, weakly curved with straight, only very slightly expanded central pores. Terminal fissures hooked, clearly visible in LM. Transapical striae parallel to weakly radiate, to convergent near the apices, $12-14$ in $10 \mu \mathrm{m}$.

SEM morphology (Bunger Hills 14): striae composed of apically elongated lineolae, 50-60 in $10 \mu \mathrm{m}$ (Figs 76, 77). Virgae wider than the striae (Fig. 77). Proximal raphe endings almost straight and not or only very weakly expanded (Fig. 79). Distal raphe endings with thin, strongly hooked fissures (Fig. 77). A short slit is present at both poles near the end of the terminal raphe fissures (Fig. 76). Internally, areolae covered by hymenes (Figs 78, 80). Striae lying in grooves, sunk beneath the internal valve face, bordered by well developed virgae (Figs 80, 81). Raphe sternum asymmetrically thickened due to the presence of a pronounced accessory rib (Fig. 80). Distal raphe endings terminating in small helictoglossae (Fig. 81).

Distribution: Navicula shackletoni has so far only been reported from the Antarctic Continent (East-Antarctica, Victorialand) and seems to be absent from the Subantarctic and Maritime Antarctic (see Kellogg \& Kellogg 2002 and references therein).

Taxonomical remarks: $N$. shackletoni clearly belongs to Navicula s.s. (sect. Naviculae lineolatae sensu Cleve 1895) (Lange-Bertalot 2001) although Mills (1933-1935) transferred the species to the genus Pinnularia, most probably because West \& West (1911) indicated that the species might belong to this genus. West \& WeSt (1911) also described a variety 'pellucida' that, according to the authors, should be separated from the nominate variety type on one hand by having two shorter striae on either side of the central area and on the other hand by having a much great width in girdle view. Since mixed populations containing both morphotypes can be found in the same sample, it is rather unclear whether they should be separated or not based on this one feature. We suggest therefore considering this variety as a synonym of Navicula shackletoni.

In 2000, Alfinito \& CAVACINI described a new species, Navicula skuae, which appears to be closely related to $N$. shackletoni. The features used to distinguish both species were based on the original drawings from West \& West of $N$. shackletoni. These drawings and the original description however do not show or mention the presence of hooked terminal raphe fissures we observed in the type material of this species, the lack of which was consequently used by AlFinito \& CAVACINI 2000 to separate $N$. skuae from $N$. shackletoni. A second discriminating feature used, was the number of transapical striae in 10 $\mu \mathrm{m}$ being 16-20 in $N$. skuae but only 10-12 in $N$. shackletoni. Both our own observations and $\mathrm{SABBE}$ et al. (2003) contradict these findings in counting 12-14 for N. shackletoni and 14-15 for N. skuae (illustrations in Alfinito \& CAVACINI 2000). We therefore have to conclude that both species are conspecific and that $N$. skuae should be considered as a synonym of $N$. shackletoni.

\section{Nitzschia westiorum Kellogg et Kellogg in KellogG et al. (Figs 82-92)}

Basionym: Nitzschia westii Kellogg et KellogG in Kellogg et al. (1980), Palaeogeography, Palaeoclimatology, Palaeoecology 30: p. 185, Plate 2 Fig. 7.

Original name in West \& West (1911): Fragilaria tenuicollis HeIB. var. antarctica W. et G.S. WEST

Original description (WeST \& WeST 1911): Var. polis valvae valde productis et leviter subcapitatis ; striis non radiatis, 16 in $10 \mu \mathrm{m}$. Longitudo valvae $37 \mu \mathrm{m}$, latitudo $3 \mu \mathrm{m}$.

Translation of the original description: variety with valve poles strongly produced and slightly subcapitate. Striae not radiate, 16 in $10 \mu \mathrm{m}$. Valve length $37 \mu \mathrm{m}$, width $3 \mu \mathrm{m}$.

Lectotype (here designated): slide BM34122 (Natural History Museum, London, UK) 

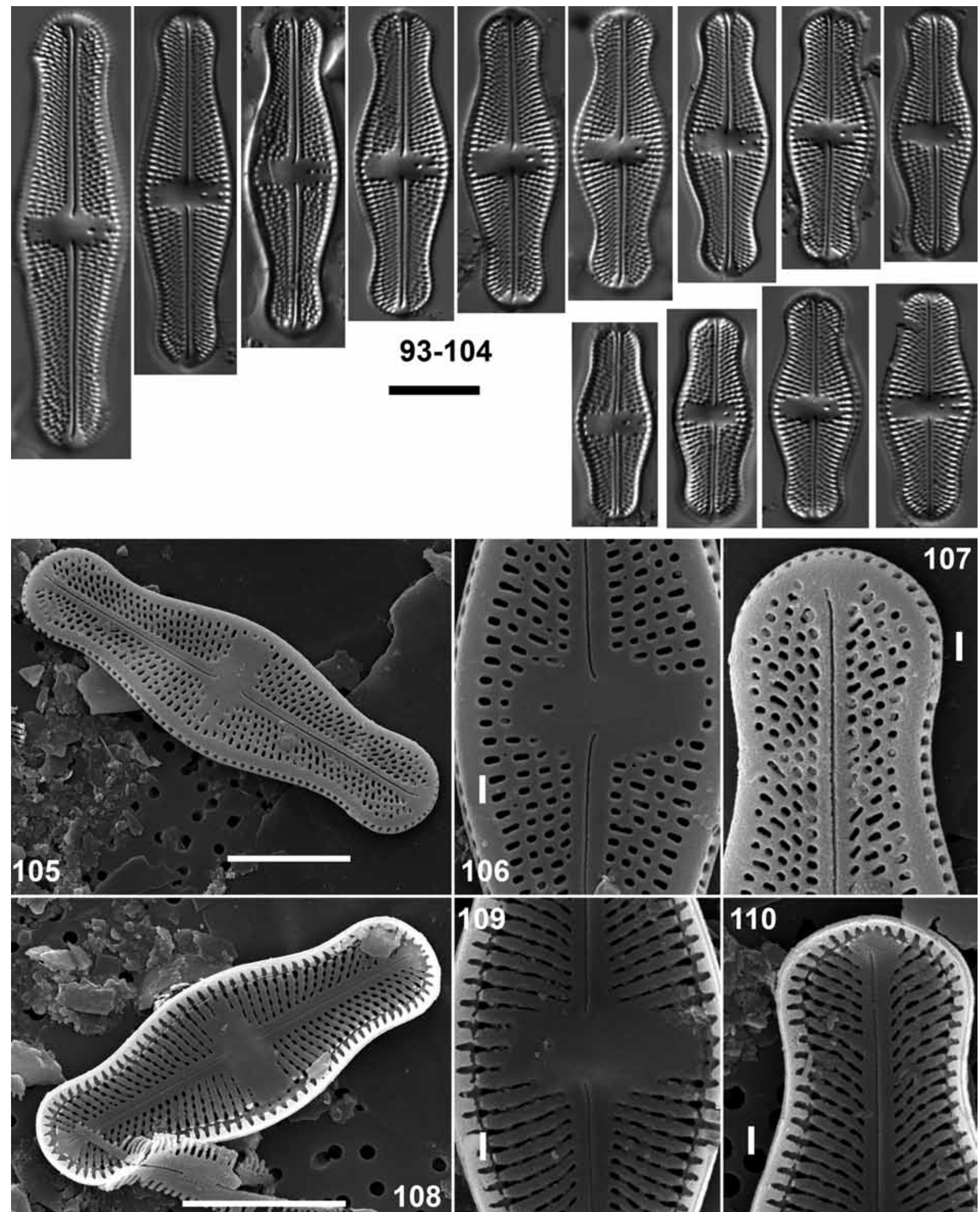

Figs 93-110. Luticola pseudomurrayi : (93-104) light microscopical images of the type population of Langhovde, Antarctica; (105) Scanning Electron Microscope (SEM) external view of an entire valve; (106) SEM external detail of the central area showing the position of the stigma; (107) SEM external detail of the apex with the very short terminal fissures; (108) SEM internal view of an entire valve; (109) SEM internal view of the central area; (110) SEM internal view of the valve apex with the helictoglossa. Scale bars $(93-105,108) 10 \mu \mathrm{m} ;(106-107,109-110) 1 \mu \mathrm{m}$. 
LM morphology: valves linear with parallel margins (Figs 82-87). Apices rostrate to capitateproduced. Valve length $16-45 \mu \mathrm{m}$, width 3-4 $\mu \mathrm{m}$ $(\mathrm{n}=25)$. Transapical striae parallel and equidistant throughout the entire valve, $14-16$ in $10 \mu \mathrm{m}$. Valves crossed by transapical, raised ribs. Near the valve margin, some striae are bifurcating. Areolae not discernible in LM.

SEM morphology (Taylor Valley, C14-77-1B): raphe keel rather narrow, slightly elevated, situated at the valve margin (Fig. 89). Striae biseriate composed of two rows of small, rounded areolae, occasionally a third row of areolae is visible near the raphe keel (Fig. 90). Striae separated by thickened costae, almost as broad as the striae, connected to the raphe keel. Raphe continuous from pole to pole (Fig. 89). Internally, double or triple rows of areolae visible in the striae (Fig. 92). Fibulae very small. Distal raphe endings terminating in small helictoglossae, visible in the last foramen before the apices (Fig. 91, see arrow).

Distribution: Nitzschia westiorum is a typical Antarctic endemic and has so far been observed in the Ross Sea Embayment (Taylor Valley, McMurdo, Victoria Land) (Kellogg \& KellogG 2002 and references therein) and East-Antarctica (a.o. Spaulding et al. 1997). The species is absent from the Maritime Antarctic Region.

Taxonomical remarks: this taxon was described by WEST \& WEST (1911) as a variety of Fragilaria tenuicollis. WeSt \& WEST (1911) however could not observe in LM the particular ultrastructure outlined above. BAKER (1967) found the species in Lake Miers (South Victoria Land) and reported it as Nitzschia antarctica (W. et G.S. WeST) BAKER, a name that was however already in use for a marine species (OKuno 1954). Kellogg et al. (1980) renamed it Nitzschia westii in honour of WeST \& West who originally described it. Since Kellogg et al. (1980) stated that the specific epithet was given in honour of both W. WeST \& G.S. West, the name should be 'westiorum' and not 'westii' (ICBN, Article 61, MCNeILL et al. 2006).

\section{Species described as new in this paper}

Luticola pseudomurrayi VAN DE VIJVER et Tavernier sp. nov. (Figs 93-110)

Diagnosis: Valvae lanceolatae ad late ellipticae parte centrali paene elliptica apicibusque clare constrictis, late rotundatis, capitatis ad subcapitatis. Longitudo

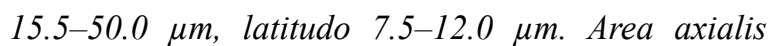
angusta, linearis, leviter dilatata ad aream centralem. Zona hyaline adest in apicibus. Area centralis formans fasciam rectangularem ad transverse-ellipticam, emarginatam striis irregulariter abbreviates. Stigma solitaria adest. Raphe recta, filiformis terminationibus centralibus indistinctis, leviter deflexis. Fissurae terminales curtae, leviter deflexae. Striae radiatae apud aream centralem, magis radiatae ad apices, 1720 in $10 \mu \mathrm{m}, 21-22$ in $10 \mu \mathrm{m}$ ad apices. Areolae 4-5 per striam, discernendae in microscopio photonico.

Holotypus (here designated): BR-4245 (National Botanic Garden, Meise, Belgium)

Isotypi: PLP-193 (University of Antwerp, Belgium), BRM-ZU8/29 (Hustedt Collection, Bremerhaven, Germany)

Type locality: lake LA9 (69 $12.111^{\prime}$ S39³8.966'E), Langhovde, Lützow Holm Bay, East-Antarctica

Etymology: the specific epithet 'pseudomurrayi' refers to the confusion that has existed for a long time with Luticola murrayi.

LM observations: valves broadly lanceolate to broadly elliptical with an almost elliptical central part and clearly constricted, broadly rounded rostrate to capitate apices (Figs 93-104). Valve length $15.5-50.0 \mu \mathrm{m}$, width 7.5-12.0 $\mu \mathrm{m}$, apex width $4.5-9.0 \mu \mathrm{m}(\mathrm{n}=35)$. Axial area narrow, linear, slightly widening towards the central area and the apices, where a wedge-shaped hyaline area is present. Central area elliptical to rectangular, bordered by several irregularly shortened striae. One isolated stigma present. Raphe filiform, straight. Central raphe endings simple, weakly deflected away from the stigma. Terminal raphe endings short, weakly deflected. Transapical striae radiate near the valve centre to more or less radiate near the apices, 17-20 in 10 $\mu \mathrm{m}$ to $21-22$ near the apices. Each stria composed of 4-5 areolae.

SEM observations: striae composed of 4-5 transapically elongated areolae of variable size, which sometimes appear to be merged in more eroded valves (Figs 105-107). Striae bordering the central area on the stigma-bearing side composed of 2-3 areolae, on the other side only one areola is present in the striae (Fig. 106). Stigma slit-like externally (Fig. 106). Central raphe endings simple, deflected (Fig. 106). Terminal raphe endings very short, deflected, ending near the last striae (Fig. 107). Internal structure difficult to resolve due to erosion of the valves (Fig.108). Occlusion type 

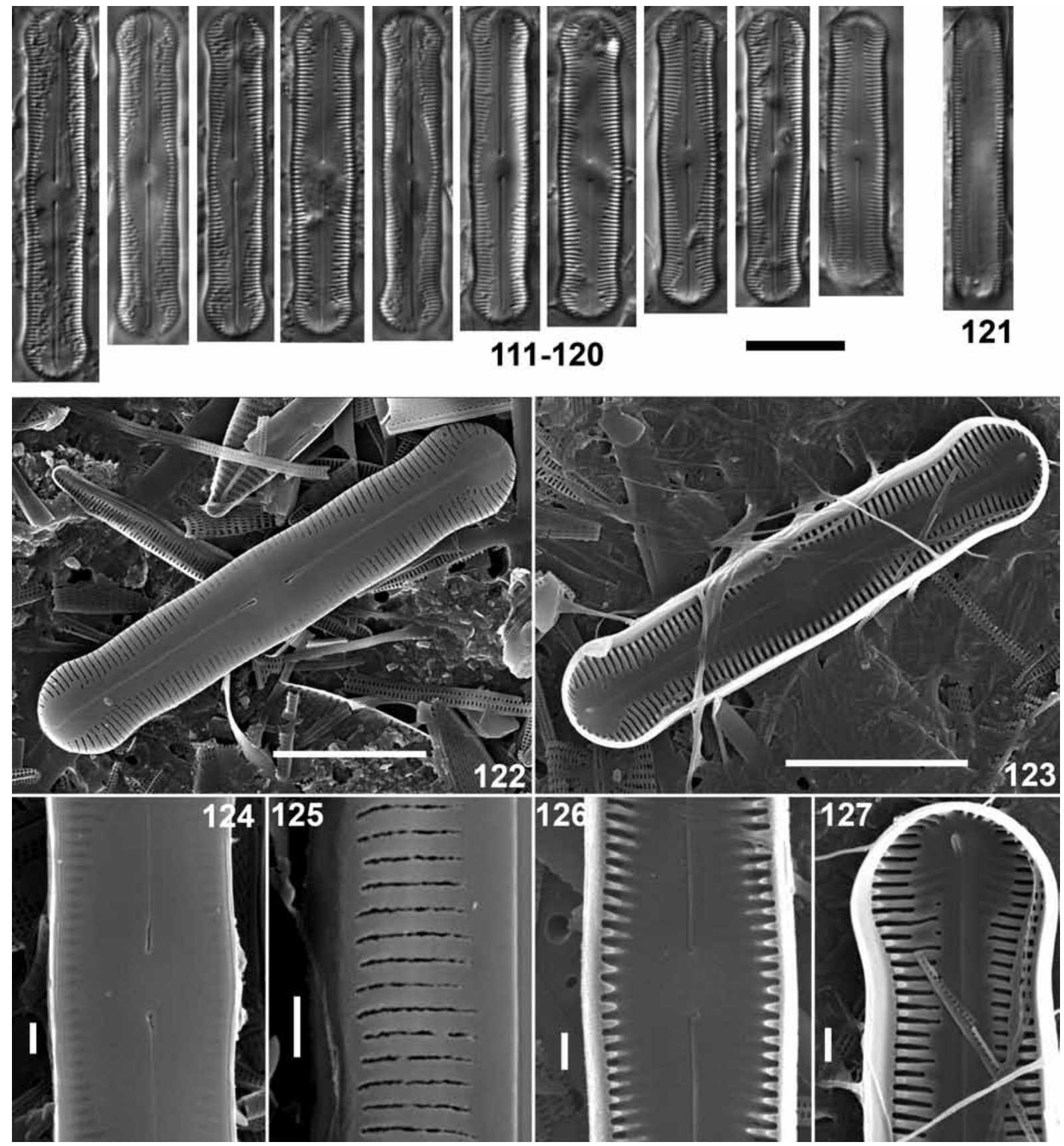

Figs 111-127. Chamaepinnularia gibsonii: (111-120) Light Microscopical (LM) images of the type population of Bunger Hills, Antarctica; (121) LM girdle view; (122) Scanning Electron Microscope (SEM) external view of an entire valve; (123) SEM internal view of an entire valve; (124) SEM external detail of the central area of an non-eroded valve; (125) SEM external detail of the valve face/mantle margin of an eroded valve. Note the uninterrupted striae continuing over the margin. (126) SEM internal view of the central area; (127) SEM internal view of the valve apex with the helictoglossa. Scale bars (111-123) 10 $\mu \mathrm{m} ;(124-127) 1 \mu \mathrm{m}$.

unknown due to erosion. Internal stigma opening consisting of an almost rounded, irregularly lipped slit (Fig. 109). Central raphe endings internally slightly deflected towards the stigma, terminating in a weakly raised central nodule. Terminal raphe endings with small helictoglossae (Fig. 110).

Ecology and associated diatom flora: out of 27 studied lakes (Tavernier et al., unpublished data) from four regions in Lützow Holm Bay (East and West Ongul Island, Langhovde and Skarvsnes), L. pseudomurrayi has been observed in 22 lakes. The largest population was found in lake LA9, where the species occurred co-dominantly with Chamaepinnularia cymatopleura in a littoral epipsammic mat sample. The diatom community 
was furthermore composed of Amphora veneta KüTZING and Navicula gregaria DonKIN in relatively small abundances. The lake has an alkaline $\mathrm{pH}$ (8.17) with a very high specific conductance $\left(4.03 \mathrm{mS} . \mathrm{cm}^{-1}\right)$ and very low nutrient levels. Another important population was found in lake LA8 (Akebi Lake, 69¹2.089'S-39³9.047'E), where the community was composed of the same diatom species, along with Achnanthes brevipes C.AgardH and Navicula phyllepta KüTZING in small abundances.

Taxonomical remarks: to date, Luticola pseudomurrayi has usually been identified as Luticola murrayi on the basis of the original description and illustration of $L$. murrayi by WEST $\&$ West (1911). L. pseudomurrayi however does not fit into this description (cf. discussion under Luticola murrayi). Even the largest specimens of $L$. pseudomurrayi never have the typical L. murrayi valve outline. L. pseudomurrayi resembles Luticola gaussii, a taxon found in similar environments on the Antarctic Continent that was reported and illustrated by West \& WeST (1911) as Navicula (Pinnularia) globiceps. Both species however can be separated by differences in valve outline, shape of the apices and stria structure. L. gaussii has a rounded central area whereas in L. pseudomurrayi it is more elliptic-lanceolate. Moreover, $L$. gaussii has distinctly capitate apices with a narrow constriction between the valve center and the apices. This constriction is less pronounced in $L$. pseudomurrayi. The striae in $L$. gaussii are composed of maximum 3, sometimes 4 small areolae (in contrast with L. pseudomurrayi which has 4-5 areolae). Other capitate Luticola species such as L. gigamuticopsis VAN DE VIJVER or L. caubergsii VAN DE VIJVER have so far never been observed on the Antarctic Continent and seem to be restricted to the Maritime Antarctic Region (VAN DE ViJver \& Mataloni 2008). Luticola gigamuticopsis has a more elliptic valve outline with larger valve dimensions whereas $L$. caubergsii has typically rostrate apices (VAN DE ViJver \& Mataloni 2008). The most widespread Luticola species in the Antarctic Region is $L$. muticopsis (VAn Heurck) D.M. ManN. However, the valve outline with one straight and one convex margin, the typical raphe system with the short, bent proximal raphe endings and the lower areola number per stria make confusion with $L$. pseudomurrayi entirely impossible (VAN DE VIJVER \& MatALONI 2008).
Chamaepinnularia gibsonii VAN DE VIJVER sp. nov. (Figs 111-127)

Diagnosis: Frustulae in aspectu cingulari rectangulares. Cellulae solitariae, numquam formantes colonias. Valvae lineares marginibus parallellis clare triundulatis, apicibusque subcapitatis, late rotundatis, etiam in speciminibus minutissimis. Valvae lanceolatae vel lineari-ellipticae numquam observatae. Longitudo

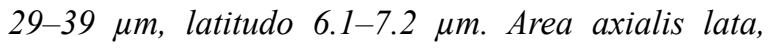
linearis, dilatata ad aream centralem. Ad apices, area axialis abrupte dilatata formans zonam hyalinam ellipticam. Area centralis lata, elliptico-lanceolata ad ovalis, formata striis centralibus graduatim abbreviates. Raphe filiformis, recta terminationibus centralibus non deflexis, leviter expansis. Fissurae terminals uncinatae. Striae leviter radiatae in medio parte valvae, convergentes ad apices, 22-24 in 10 $\mu$ m. In apices, striae irregulariter interruptae.

Holotypus (here designated): BR-4246 (National Botanic Garden, Meise, Belgium)

Isotypi: PLP-194 (University of Antwerp, Belgium), BRM-ZU8/30 (Hustedt Collection, Bremerhaven, Germany)

Type locality: lake 14, Bunger Hills, Antarctic Continent (coll. date January 2000)

Etymology: the species is named after our colleague Dr. John Gibson (University of Tasmania, Australia) in recognition of his Antarctic research.

LM observations: frustules in girdle view rectangular (Fig. 121). Valves always linearrectangular with slightly tri-undulated margins and rostrate-capitate, broadly rounded apices. Valve length $29-39 \mu \mathrm{m}$, width 6.1-7.2 $\mu \mathrm{m}(\mathrm{n}=17)$. Axial area broad, linear, widening to the central area. Near the apices, axial area wider, forming an elliptical to circular hyaline area. Central area wide, elliptic-lanceolate to oval. Raphe filiform, straight to slightly expanded, in LM almost straight central raphe endings. Terminal fissures hooked, distinct in LM. Transapical striae slightly radiate near the valve center, becoming convergent towards the apices, 22-24 in $10 \mu \mathrm{m}$. Near the apices, striae appear irregularly interrupted around the raphe sternum.

SEM observations: externally, alveoli covered by hymen (Fig. 124). Striae continue across the valve face/mantle margin (Fig. 125). Central raphe endings expanded and slightly deflected to the opposite side of the terminal fissures (Figs 122, 124). Terminal fissures long, hooked, continuing onto the mantle (Fig. 122). Internally, alveoli 
not occluded (Fig. 123). Close to the apices, striae may partly be covered (Fig. 127). Near the valve face/mantle margin, short, blunt spine-like projections internally present on the virgae (Figs 126, 127; cf. C. cymatopleura). Internal central raphe endings bent in the same direction (Fig. 126). Central nodule only weakly developed (Fig. 126). Terminal raphe endings lying in small helictoglossae (Fig. 127).

Ecology and associated diatom flora: So far $C$. gibsonii has only been observed in one lake of the Bunger Hills but due to confusion with the widespread Chamaepinnularia cymatopleura, it is possible that the exact distribution is not precisely known. Lake 14 in the Bunger Hills where the species was found, is a relatively large saline lake covered with an orange/brown microbial mat (GiBson et al. 2006). Dominant species in the lake include Craspedostauros laevissimus, Navicula directa (W. SмITH) RalfS, N. shackletoni and several so far unidentified Amphora, Navicula and Nitzschia species.

Taxonomical remarks: Chamaepinnularia gibsonii closely resembles $C$. cymatopleura (Figs $1-23$ ) but can be separated in valve width shape (6.1-7.2 $\mu \mathrm{m}$ vs. $4.5-5.1 \mu \mathrm{m}$ in C. cymatopleura) and shape (always linear-rectangular). In the typical C. cymatopleura populations of the Bunger Hills, valves with a $C$. gibsonii morphology are completely absent despite the fact that specimens of similar length $(30-35 \mu \mathrm{m})$ were present. Moreover, the apices of $C$. gibsonii are always wider than the valve center, a feature never observed in $C$. cymatopleura. Chamaepinnularia gibsonii cannot be confused with other Chamaepinnularia species present in the Antarctic Region (such as C. krookii, C. krookiiformis or C. australomediocris, STERKEN et al. unpubl. data.).

\section{Acknowledgments}

The authors wish to thank Mr. Marcel Verhaegen and Mrs. Myriam de Haan for their technical support with the SEM. Mr. Pierre Compère is thanked for stimulating discussions on the International Code of Botanic Nomenclature. Prof. Dr. David G. Mann is thanked for his valuable taxonomic comments. Dr. Sarah Spaulding is acknowledged for giving us the permission to reproduce the Luticola murrayi pictures from the Freshwater Antarctic Diatoms website. Dr. Paolo Cavacini is thanked for the pictures of Navicula glaberrima. Dr. David Williams (Natural History
Museum) is thanked for sending the West \& West slides. Elie Verleyen is a post-doctoral fellow at the FWO.

\section{References}

Alfinito, S. \& CAVAcinI, P. (2000): Navicula skuae sp. nov., a freshwater dieton from Continental Antarctica. - Diatom Research 15: 1-9.

BAKER, A.N. (1967): Algae from Lake Miers, a solarheated Antarctic lake. - New Zealand Journal of Botany 5: 453-468.

BARBER, H.G. \& HAwORTH, E.Y. (1981): A guide to the morphology of the diatom frustule. - Freshwater Biological Association Scientific Publication 44: 1-111.

BRown, N.E. (1920): Some new and old diatoms from the Antarctic Region. - English Mechanic and World of Science 111: 210-211.

CARLSON, G.W.F. (1913): Süsswasseralgae aus der Antarktis, Südgeorgien und den Falkland Inseln. - Wissenschaftliche Ergebnisse der Schwedischen Südpolar-Expedition 19011903, unter leitung von dr. Otto Nordenskjøld: 4 (Botanique): $1-94+3$ plates.

Cavacini, P.; Tagliaventi, N. \& Fumanti, B. (2006): Morphology, Ecology and distribution of an endemic Antarctic lacustrine diatom: Chamaepinnularia cymatopleura comb. nov. Diatom Research 21: 57-70.

Cox, E.J. (1999): Craspedostauros gen. nov., a new diatom genus for some unusual marine raphid species previously placed in Stauroneis Ehrenberg and Stauronella Mereschkowsky. European Journal of Phycology 34: 131-148.

Cremer, H.; Roberts, D.; McMinn, A.; Gore, D. \& Melles, M. (2003): The Holocene Diatom Flora of Marine Bays in the Windmill Islands, East Antarctica. - Botanica Marina 46: 82-106.

Esposito, R.M.M.; Spaulding, S.A.; McKnight, D.M.; Van de ViJVer, B.; Kopalová, K.; Lubinski, D.; Hall, B. \& WhitTAKER., T. (2008): Inland diatoms from the McMurdo Dry Valleys and James Ross Island, Antarctica. - Botany 86: 1378-1392.

Fritsch, F.E. (1912): Freshwater algae. - In: Natural History. London. British Museum. - National Antarctic Expedition 1901-1904. v.6 (Zoology \& Botany): 1-60.

Fritsch, F.E. (1917): Freshwater algae. British Antarctic ("Terra Nova") Expedition, 1910. Natural History Report 1-17.

Gibson, J.A.E.; Roberts, D. \& VAN DE ViJver, B. (2006): Salinity control of the distribution of diatoms in lakes of the Bunger Hills, East Antarctica. Polar Biology 29: 694-704.

Grove, W.B. (1919): George Stephen West, M.A., 
D.Sc., F.L.S. (1876-1919.) - Journal of Botany 57: 283-284.

HÅKansson, H. \& Jones, V.J. (1994): The compiled freshwater diatom taxa list for the maritime region of the South Shetland and South Orkney Islands. - In: Hamilton, P.B. (ed.): Proceedings of the Fourth Arctic-Antarctic Diatom Symposium Workshop. - Canadian Technical report of Fisheries and Aquatic Sciences 157: $77-83$.

Heiden, H. \& Kolbe, R.W. (1928): Die marinen Diatomeen der Deutschen Südpolar-Expedition 1901-1903. - In: E. vON DRYgalsky (ed.): Deutsche Südpolar-Expedition 1901-1903 im Auftrage des Reichsministeriums des Innern. Vol. 8/5 (Botanik). - pp. 447-715, Walter de gruyter \& co, Berlin und Leipzig.

Hendey, N.I. (1964): An introductory account of the smaller algae of British coastal waters. Part V. Bacillariophyceae (Diatoms). - 317 pp. (+44 plates), Her Majesty's Stationery Office, London.

Holmboe, J.D. (1902): IV. Navicula mutica Kütz. Aus dem antarktischen Festlande. - Nyt Magazin for Naturvidenskaberne, Christiana 40: 221-222.

Hustedt, F. (1961-1966): Die Kieselalgen Dutschlands, Österreichs unde der Schweiz mit Berücksicht der übrigen Länder Europas sowie der Angrenzenden Meeresgebiete. In: Dr. Rabenhirst Kryptogamen Flora von Deutschland, Österreich und der Schweiz 7: 1-815.

KellogG, D.E.; Stuiver, M.; KellogG, T.B. \& Denton, G.H.D. (1980): Non-marine diatoms from Late Wisconsin perched deltas in Taylor Valley, Antarctica. - Palaeogeography, Palaeoclimatology, Palaeoecology 30: 157189.

KellogG, D.E. \& Kellogg, T.B. (1987): Diatoms of the McMurdo Ice Shelf, Antarctica. - Palaeogeograpgy, Palaeoclimatology, Palaeoecology 60: 77-96.

Kellogg, T.B. \& KellogG, D.E. (2002): Non-marine and littoral diatoms from Antarctic and subantarctic regions. Distribution and updated taxonomy. - Diatom monographs 1: 1-795.

Ko-BAyAshi, T. (1963): Variations on some pennate diatoms from Antarctica (Part 1): III. Variations of Navicula muticopsis Van Heurck var. muticopsis f. murrayi (W. \& G.S. WEST) Ko-BAYASHI. - Japanese Antarctic Research Expedition 1956-1962, Scientific Reports Series E 18: 1-20 + 16 plates.

KrassKe, G. (1938): Beiträge zur Kenntnis der Diatomeenflora von Island und Spitzbergen. Archiv für Hydrobiologie und Planktonkunde 33: 503-533.

Lange-Bertalot, H. (2001): Navicula sensu stricto,
10 genera separated from Navicula sensu lato, Frustulia. - Diatoms of Europe 2: 1-526.

McNeill, J.; Barrie, F.R.; Burdet, H.M.; Demoulin, V.; Hawksworth, D.L.; Marhold, K.; Nicolson, D.H.; Prado, J.; Silva, P.C.; Skog, J.E.; Wiersema, J.H. \& Turland, N.J. (2006): International Code of Botanical Nomenclature, Vienna Code. -568 pp., A.R.G. Gantner Verlag K.G., Ruggell, Liechtenstein.

Mills, F.W. (1933-1935): An index to the genera and species of the Diatomaceae and their synonyms 1816-1932. - 526 pp., Wheldon \& Wesley, London.

OKunO, H. (1954): Electron microscopical study on Antarctic diatoms. - Journal of Japanese Botany 29: $18-25$.

Paddock, T.B.B. (1988): Plagiotropis Pfitzer and Tropidoneis CLEVE, a summary account. Bibliotheca Diatomologica 16: 1-152.

Patrick, R. \& Reimer, C.W. (1975): The diatoms of the United States exclusive of Alaska and Hawaii. Entomoneidaceae, Cymbellaceae, Gomphonemaceae, Epithemiaceae. Monographs of the Academy of Natural Sciences of Philadelphia 2: 1-213.

Roebuck, W.D. (1914): In memory of William West (1848-1914.) (with portrait). - Journal of Botany 52: 161-164.

Round, F.E.; Crawford, R.M. \& ManN, D.G. (1990): The diatoms. Biology \& Morphology of the genera. Cambridge University Press, Cambridge. -747pp., Cambridge, UK.

Sabbe, K.; Verleyen, E.; Hodgson, D.A.; Vanhoutte, K. \& VyVERMAN, W. (2003): Benthic diatom flora of freshwater and saline lakes in the Larsemann Hills and Rauer Islands, East-Antarctica. Antarctic Science 15: 227-248.

Spaulding, S.A. \& Stoermer, E.F. (1997): Taxonomy and distribution of the genus Muelleria Frenguelli. - Diatom Research 12: 95-115.

Spaulding, S.A.; McKnight, D.M.; Stoermer, E.F. \& Doran, P.T. (1997): Diatoms in sediments of perennially ice-covered Lake Hoare, and implications for interpreting lake history in the dry valleys region of Antarctica. - Journal of Paleolimnology 17: 403-420.

Spaulding, S.A.; Kociolek, J.P. \& Wong, D. (1999) A taxonomic and systematic revision of the genus Muelleria (Bacillariophyta). - Phycologia 38: 314-341.

Spaulding, S.; Esposito, R.; Lubinski, D.; Horn, S.; Cox, M.; McKnight, D.; Alger, A.; Hall, B.; Mayernick, M.; Whittaker, T. \& YAng, C. (2011): Antarctic Freshwater Diatoms web site, McMurdo Dry Valleys LTER, visited 18 Mar 2011 at http:/huey.colorado.edu/diatoms/

Van de Vijver, B.; Beyens, L. \& Lange-Bertalo,T H. (2004): The genus Stauroneis in Arctic and 
Antarctic locations.-Bibliotheca Diatomologica 51: 1-311.

VAn de Vijver, B. \& Mataloni, G. (2008): New and interesting species in the genus Luticola D.G. Mann (Bacillariophyta) from Deception Island (South Shetland Islands). - Phycologia 47: 451-467.

Van de Vijver, B.; Mataloni, G.; Stanish, L. \& Spaulding, S.A. (2010): New and interesting species of the genus Muelleria (Bacillariophyta) from the Antarctic Region and South Africa. Phycologia 49: 22-41.

Van de Vijver, B.; Sterken, M.; Vyverman, W.; Mataloni, G.; Nedbalová, L.; Kopalová, K.; Elster, J.; Verleyen, E. \& Sabbe, K. (2010): Four new non-marine diatom taxa from the Subantarctic and Antarctic Regions. - Diatom Research 25: 431-443.

VAN DER WERFF, A. (1955): A new method for cleaning and concentrating diatoms and other organisms. - Verhandlungen der Internationalen Vereinigung für theoretische und angewandte Limnologie 12: 276-277.

Van Heurck, H. (1909): Diatomées. In: Résultats du
Voyage du S.Y. Belgica en 1897-1898-1899. Rapports Scientifiques. - Botanique 6: 1-129. Antwerpen: Imprimerie J.-E. Buschmann.

Wasell, A. \& HÅkansson, H. (1992): Diatom stratigraphy in a lake on Horseshoe Island, Antarctica: a marine-brackish-freshwater transition with comments on the systematics and ecology of the most common diatoms. Diatom Research 7: 157-194.

WASELL,A. (1993): Diatom Stratigraphy and evidence of Holocene environmental changes in selected lake basins in the Antarctic and South Georgia [PhD Thesis]. - Stockholm University, Department of Quaternary Research, Stockholm.

West, W. \& West, G.S. (1911): Freshwater algae. - British Antarctic Expedition (1907-1909) Science Report, Biology 1: 263-298.

(C) Czech Phycological Society (2012)

Received June 1, 2011

Accepted July 11, 2011 